\title{
Dakwah di Media Sosial
}

\author{
Ilham Maulana ${ }^{1 *}$, Chatib Saefullah ${ }^{1}$, Tata Sukyat ${ }^{1}$ \\ ${ }^{1}$ Jurusan Komunikasi dan Penyiaran Islam, Fakultas Dakwah dan Komunikasi, UIN Sunan \\ Gunung Djati, Bandung
}

*Email:fatalombok@gmail.com

\begin{abstract}
ABSTRAK
Tujuan penelitian ini adalah untuk mengetahui peran admin sebagai da'i dalam akun Youtube Akhyar TV, metode dakwah dan pesan dakwah yang disampaikan oleh akun Youtube Akhyar TV. Untuk mendalami penelitian ini menggunakan teori citra da'i sumber buku "Dasar-dasar Ilmu Dakwah" karya (Enjang AS dan Aliyudin, 2009) dan teori S-M-R-C Berlo sumber buku "Pengantar Ilmu Komunikasi" karya (Mulyana, 2013) untuk menjawab semua permasalahan yang ada dalam penelitian. Metode yang digunakan dalam penelitian ini adalah metode analisis isi. Metode ini untuk menganalisis, menguraikan, memahami, dan menjelaskan tentang Fenomena Dakwah di Media Sosial. Hasil penelitian menunjukan bahwa peran admin adalah sebagai pengurus yang mengatur Dakwah di Media Sosial Ust. Adi Hidayat. Dakwah dalam akun Akhyar TV merupakan pengingat akan perbaikan akhlak sesuai tuntunan Qur'an dan hadist agar lebih baik. Pesan dakwahnya terbagi atas pesan dakwah Aqidah, Fiqh, dan Akhlak. Pesan dakwah yang di unggah oleh Akun Akhyar TV adalah pesan Akhlak, Aqidah.
\end{abstract}

Kata Kunci: Dakwah, Metode, Materi, Media

\section{ABSTRACT}

The purpose of this research is to know the administrator's role as a da'i on Youtube account of Akbyar TV, da'wah methods and preaching a message which delivered by Akhyar TV. The research was held to find out Da'wah through Social Media that including the role of da'i, mad'u, method, message, and media of da'wah. To explore this research, using the image (citra) theory from the source of the book. "Fundamentals of Da'wab Science (Dasar-dasar Ilmu Dakwah)" written by (Enjang AS and Aliyudin, 2009) and the Berlo S-M-R-C theory from the book of "Introduction to Communication Studies" written by (Deddy Mulyana, 2013) for solving all problems in the research. The methods which used by the writer for this research is analytical method of the contents. This method is used to analyze, describe, understand, and explain about the phenomenon of Da'wah in Social Media. The results of the

258 Diterima: Juli 2018. Disetujui: Agustus 2018. Dipublikasikan: September 2018 
research show that the administrator's role is as a manager who regulates Da'wah on Ust. Adi Hidayat's Social Media. The Da'wah on Akbyar TV account is a reminder of the improvement of character and lifestyle according to the guidance of the Qur'an and hadist in order getting better. The da'wah messages are divided into the messages of da'wah Aqeedah, Fiqh, and Morals. The most da'wah messages uploaded by the Akhyar TV Account are the message of Morals and Aqeedah.

Keywords: Khithabah, Metode, Materi, Media

\section{PENDAHULUAN}

Sejalan dengan perkembangan zaman dan perubahan informasi yang dikomandoi oleh perkembangan teknologi, tabligh mengalami perluasan makna. Tabligh tidak lagi dipahami sebagai proses "penyampaian pesan dengan lisan" tetapi juga merambah pada dimensi-dimensi lain yang lebih luas. Dalam perkembangannya, tabligh lebih dipahami dalam tiga konteks utama, yakni; khitobah (pidato), khitabah (tulis-menulis), dan i'lam (peragaan). Dua term yang disebut di awal mungkin terdengar lebih akrab ditelinga kita karena selama ini, kedua istilah itu telah populer dan banyak digunakan bahkan kita dapat menemuinya dalam berbagai literatur klasik sekalipun. Di antara kitab yang membahas tentang i'lam 'adalah "Nadhoriyatu al-'Tlàm fi al-Da'wah al- Islam iyah" yang ditulis oleh Aminah al-Shawi dan Abdul Aziz Syarof Dalam kitabnya, ia mengatakan bahwa dakwah Islam merupakan seruan paling istimewa di antara seruan-seruan ketuhanan lainnya (Aminah al-Shawi, Abdul Aziz Syarof, t.t 198: 199).

I'lam kerangka sistem tabligh, berarti proses penyiaran dan penyebarluasan ajaran Islam, baik secara lisan maupun tulisan dengan cara menggunakan media yang disampaikan kepada internal umat Islam atau kepada komunitas tertentu yang non-muslin (futûhât). Oleh sebab itu, i'lâm dapat disebut sebagai difusi, yaitu merupakan bagian dari tabligh, dalam bentuk penyiaran dan penyebarluasan ajaran Islam melalui media.

Dalam makna yang lebih luas, i'lam dapat dipahami sebagai kegiatan penyiaran Islam dalam bentuk menyampaikan informasi dan pengetahuan secara jelas dan hati-hati, berdasarkan hasil pertimbangan akal yang didasarkan pada pemahaman Al-Qur'an sebagaimana firman Allah: "Sesungguhnya kami telah menurunkan Al-Qur'an dalam Bahasa Arab supaya kamu dapat memahaminya."

Secara spesifik, bentuk kegiatan penyiaran ini dapat mengunakan media elektronik baik Radio maupun Televisi. Kemudian, informasi sebagai bagian dari unsur penyiaran, dalam hal ini merupakan elemen dasar komunikasi, serta salah satu dari empat fungsi komunikasi yang dikenal. Keempat fungsi tersebut yaitu fungsi instruksi dan komando, fungsi memengaruhi dan persuasif, fungsi 
integrasi dan fungsi informasi.

Di era modern ini, manusia dimudahkan dalam melakukan berbagai hal salah satunya dalam kemudahan berinteraksi dan transaksi. Kesibukan yang dimiliki oleh setiap orang membuat mereka mencari sesuatu dengan cara yang instan. Kemajuan ilmu pengetahuan dan teknologi (IPTEK) di era global sekarang ini memberikan kontribusi yang sangat berarti terhadap perubahan pola hidup dan kehidupan manusia. Salah satu kemudahan yang diciptakan adalah berinteraksi dan transaksi melalui internet. Semakin berkembangnya teknologi dunia maya atau internet, interaksi dapat dilakukan tanpa harus berada dalam ruang dan waktu yang bersamaan.

Menurut Anthony Giddens, dengan datangnya modernitas, ruang semakin terpecah dari tempatnya (George Ritzer, 2003: 234). Dapat dilihat bahwa manusia menciptakan interaksi baru tanpa harus bertemu secara fisik, yang salah satunya dilakukan melalui internet khususnya media sosial. Media sosial memudahkan user untuk membuat konten dan aplikasi. User dapat berinteraksi dan bertukar wawasan dengan user lain. Media sosial juga bisa disebut sebagai media yang bebas namun harus bertanggung jawab.

Orang-orang mulai cenderung bergantung pada teknologi, alangkah baiknya jika teknologi tersebut menjadi salah satu sarana untuk berdakwah. Kita yang memiliki kemampuan agama dengan baik dapat menyebarluaskannya dengan cara mengunggah video ceramah kita di YouTube.com, sehingga kita dapat mengajak kepada kebajikan dan mencegah dari hal-hal yang mungkar. Lewat media ini kita bisa mengamalkan pesan secara benar dan tepat sesuai kondisi zamannya.

Pada Akhir-akhir ini banyak sekali bermunculan da'i-da'i dengan menggunakan berbagai macam metode dakwah, sebetulnya tujuan mereka sama yaitu menyebarkan agama Islam, serta berbuat amar ma'ruf dan nahi mungkar. Dakwah yang baik bukanlah dakwah yang bersifat menggurui, betapa pun misalnya disampaikan oleh seseorang dengan kualifikasi yang cukup memiliki bobot (Daulay, 2001: 4).

Melihat perkembangan zaman yang semakin pesat dewasa ini, komponen- komponen dakwah tersebut juga dituntut mengikuti perkembangan yang berjalandi era modern supaya aktifitas dakwah lebih bisa diterima oleh masyarakat sebagai satu elemen tersendiri bagi proses modernisasi.

Ust Adi Hidayat Lc., M.A beliau adalah seorang da'i yang menyampaikan pesan dakwah melalui media sosial youtube. beliau dan tim selalu memposting setiap kegiatan berdakwah ke channel youtube nya yaitu "Akhyar TV". Tidak hanya pengetahuan agama yang akan dapat dari channel Akhyar TV, tetapi juga ciri khas retorika dan hafalan- hafalan quran dan hadist dari Ust Adi Hidayat saat menyampaikan dakwahnya.

Berdasarkan permasalahan diatas, dapat dirumuskan beberapa masalah 
yakni bagaimana peran admin pada akun Youtube Akhyar TV, bagaimana metode dakwah Ust. Adi Hidayat di Media Sosial Youtube Akhyar TV, pesan dakwah yang terdapat pada akun Youtube Akhyar TV. Metode yang digunakan dalam penelitian ini yakni metode analisis isi yang bertujuan untuk menggambarkan dan menjelaskan terkait dengan Dakwah di media sosial Ustadz Adi Hidayat. Teknik pengumpulan yakni dengan proses observasi, wawancara, dokumentasi.

\section{LANDASAN TEORITIS}

Model komunikasi ini dikenal dengan model S-M-C-R, kepanjangan dari Source (sumber), Message (pesan), Channel (saluran), dan Receiver (penerima). Menurut Berlo (Mulyana, 2007: 162) mengemukakan bahwa sumber adalah pihak yang menciptkan pesan, baik seseorang ataupun suatu kelompok. Pesan adalah terjemahan gagasan ke dalam kode simbolik, seperti bahasa atau isyarat, saluran adalah medium yang membawa pesan, dan penerima adalah orang yang menjadi sasaran komunikasi

Model komunikasi ini dikembangkan Berlo untuk menggambarkan hubungan antara pengirim pesan dan penerima pesan. Hambatan-hambatan komunikasi mungkin saja terjadi dan karenanya berdampak pada respon atau tanggapan yang diberikan oleh penerima pesan. Model komunikasi Berlo juga menekankan pada proses encoding dan decoding yang terjadi sebelum sumber mengirim pesan dan sebelum penerima pesan menerima pesan.

Dalam komunikasi Berlo yang menjadi saluran komunikasinya adalah udara yang menyalurkan gelombang suara. Sedangkan dalam komunikasi massa terdapat banyak saluran televisi, radio, dan sebagiannya. Model komunikasi Berlo juga melukiskan beberapa faktor pribadi yang mempengaruhi proses komunikasi seperti keterampilan berkomunikasi, pengetahuan sistem sosial, lingkungan budaya, sumber dan penerima. Pesan dikembangkan berdasarkan elemen, stuktur, isi, perlakuan, dan kode. Model berlo juga bersifat heuristic (merangsang penelitian), karena menrinci unsur-unsur yang penting dalam proses komunikasi (Mulyana, 2005: 163).

Dalam penelitian ini, berhubungan dengan komunikasi Berlo yaitu bahwa sumber berasal dari admin yang mengelola media sosial Youtube @ AkhyarTV yang menyampaikan pesan tentang ajaran kebaikkan yang dikomunikasikan melalui media Youtube yang ditunjukan kepada pengguna media sosial Youtube, dengan tujuan memperbaiki kualitas umat Islam.

Teori citra da'i menjelaskan penilaian mad'u terhadap kredibilitas da'i, apakah da'i mendapat penilaian positif atau negatif dimata mad'u. Citra yang berhubungan dengan seorang $d a^{\prime} i$ dalam perspektif komunikasi erat kaitannya dengan kredibilitas yang dimilikinya. Semakin tinggi kredibilitas da'i maka 


\section{Maulana, Ch. Saefullah, T. Sukayat}

semakin mudah mad'u menerima pesan-pesan yang disampaikan. Suatu kepribadian baru dapat dipercaya atau memiliki kredibilitas apabila ia secara konstan dan konsisten selalu menjaga ucapannya selaras dengan perilaku kesehariannya. Kredibilitas seseorang tidak tumbuh dengan sendirinya, ia harus dicapai melalui usaha yang terus menerus, harus dibina dan dipupuk, serta konsisten sepanjang hidup.

Seorang da'i yang berkredibilitas tinggi adalah seorang yang mempunyai kompentensi di bidangnya, integritas kepribadian, ketulusan jiwa, serta mempunyai status yang cukup walau tidak harus tinggi. Da'i yang akan bertugas menyebarkan nilai-nilai Tuhan niscaya harus membangun kredibilitas diri. Membekali diri dengan keilmuan, keahlian, integritas kepribadian, dan sikapsikap mental lainnya, karena da'i akan dihadapkan pada bermacam-macam situasi sosial, serta pribadi yang beragam. Dalam rangka mengoptimalkan kredibilitas dan membangun citra positif maka da'i harus melingkupi tiga dimensi : kebersihan hati, kecerdasaan pikiran dan keberanian mental (Enjang $\mathrm{dkk}, 2009:$ 120).

Kesuksesesan kegiatan dakwah ditentukan dengan kualitas dan kepribadian yang dimiliki seorang $d a^{\prime} i$. Kualitas yang dimiliki seorang $d a^{\prime} i$ maka ia akan mendapatkan kredibilitas dan citra yang positif dimata mad'u.

Dakwah dalam salah satu bentuknya melalui lisan, maka ada empat cara seorang da'i dinilai oleh mad'u nya:

Da'i dinilai dari reputasi yang mendahuluinya. Seperti karya-karya, kontribusi, jasa dan sikap yang memperindah reputasi seorang $d a^{\prime} i$. Perkenalan seorang $d a^{\prime} \imath$, mad'u menilai $d a^{\prime} i$ dari informasi yang diterimanya Dari apa yang diucapkannya, jika seseorang mengungkapkan hal-hal yang kotor tidak berarti atau rendah maka seperti itu pula kualifikasi seseorang. Cara seorang da’i menyampaikan pesan dakwahnya.

Dapat disimpulkan bahwa dakwah adalah mengajak manusia kepada jalan Allah SWT secara menyeluruh baik dengan lisan, tulisan, maupun dengan perbuatan sebagai ikhtiar supaya umat muslim mewujudkan nilai-nilai ajaran Islam dalam realitas kehidupan yang pribadi (syahiyah), keluarga (usrad), dan masyarakat (jama'ah) dalam semua segi kehidupan secara menyeluruh sehingga terwujud khairul ummah atau masyarakat madani (Enjang dkk, 2009: 5). Berikut adalah definisi dakwah menurut menurut Jamaludin Kafie (1993: 28) dakwah adalah suatu sistem kegiatan dari seseorang, kelompok, atau segolongan umat Islam sebagai aktualisasi imaniyah yang yang dimanifestasikan dalam bentuk seruan, ajakan, panggilan, undangan, doa yang disampaikan dengan ikhlas dengan menggunakan metode, sistem, dan bentuk tertentu, agar mampu menyentuh kalbu dan fitrah seseorang, sekeluarga, sekelompok, masa dan masyarakat manusia, supaya dapat mempengaruhi tingkah laku untuk mencapai suatu tujuan tertentu. 
Secara umum definisi dakwah yang dikemukakan para ahli di atas menunjukan pada kegiatan yang bertujuan perubahan positif dalam diri manusia. Perubahan positif tersebut diwujudkan dengan peningkatkan iman. Peningkatan Iman termanifestasikan dalam peningkatan pemahaman, kesadaran, dan perbuatan (Aziz 2009: 18-19).

Dakwah dalam pelaksanaannya terdapat dua dimensi besar, yang pertama adalah dimensi kerisalahan (bi absan al-qawl) yang mencangkup penyampaian pesan kebenaran dan yang kedua adalah dimensi kerahmatan (bi ahsan al amal) mencangkup pengaplikasian nilai kebenaran (Kusnawan, 2009:16).

Dimensi kerisalahan (bi absan qawl) mencoba menumbuhkan kesadaran diri dalam individu atau masyarakat tentang kebenaran nilai dan pandangan secara Islam i, sehingga terjadi proses komunikasi dan internalisasi nilai Islam sebagai nilai hidupnya. Islam sebagai sumber nilai dan dakwah sebagai proses alih nilai.

Dimensi kerisalahan terdapat dua bentuk tuturan, yakni bentuk irsyad dan tabligh. Irsyad adalah penyebaran ajaran Islam yang sangat spesifik di kalangan sasaran tertentu. Irsyad menampilkan hubungan personal antara pembimbing dengan terbimbing. Irsyad lebih berorientasi pada pemecahan masalah individual yang dialami terbimbing. Irsyad meliputi bimbingan, konseling, penyuluhan, dan Psikoterapi Islam. Irsyad memberitahukan dan membimbing terhadap individu, dua orang, tiga orang, atau kelompok kecil (nasihab) atau memberi solusi atas permasalahan kejiwaan yang dihadapi (Kusnawan, 2009: 16).

Berbagai dimensi dan bentuk dakwah fokus kegiatannya terdiri dari berbagai ragam kegiatan. Irsyad meliputi bimbingan dan penyuluhan, sedangkan Tabligh kajian dakwahnya melalui media mimbar, media cetak, maupun media audio visual lainnya (Kusnawan, 2009: 18).

Dimensi kerahmatan (bi absan al-amal) mengacu pada firman Allah SWT, Q.S surat Al-Anbiya ayat 107. Dimensi kerahmatan merupakan upaya mengaktualisasi Islam sebagai rahmat (jalan hidup yang mensejahterakan dan membahagiakan) dalam kehidupan umat manusia (Kusnawan, 2009: 24).

Menurut Arifin (2011: 16), dimensi dakwah dari beberapa unsur dakwah yang didalamnya. Unsur-unsur tersebut terjadi karena adanya fenomena keagamaan yang bersifat ideal normatif sekaligus juga merupakan fenomena sosial yang rasional, aktual, dan empiris sebagai sunatullah.

media sosial adalah medium internet yang memungkinkan pengguna merepresentasikan dirinya maupun berinteraski, bekerjasama, berbagi, berkomunikasi, dengan pengguna lain, dan membentuk ikatan sosial secara virtual (Nasrullah, 2017: 13).

YouTube adalah sebuah situs web berbagi video yang dibuat oleh tiga 
mantan karyawan PayPal pada Februari 2005. Situs ini memungkinkan pengguna mengunggah, menonton, berbagi video dan untuk menampilkan berbagai macam konten video buatan pengguna, termasuk klip film, klip TV, dan video musik. Selain itu ada pula konten amatir seperti blog video, video orisinal pendek, dan video pendidikan.

\section{HASIL DAN PEMBAHASAN}

Adi Hidayat, Lahir di Pandeglang, Banten, 11 September 1984. Beliau memulai pendidikan formal di TK Pertivi Pandeglang tahun 1989 dan lulus dengan predikat siswa terbaik. Kemudian melanjutkan pendidikan dasar di SDN Karaton 3 Pandeglang hingga kelas III dan beralih ke SDN III Pandeglang di jenjang kelas IV hingga VI. Di dua sekolah dasar ini beliau juga mendapat predikat siswa terbaik, hingga dimasukan dalam kelas unggulan yang menghimpun seluruh siswa terbaik tingkat dasar di Kabupaten Pandeglang.

Dalam program ini, beliau juga menjadi siswa teladan dengan peringkat pertama. Dalam proses pendidikan dasar ini, Adi Hidayat kecil juga disekolahkan kedua orang tuanya ke Madarasah Salafiyyah Sanusiyyah Pandeglang. Pagi sekolah umum, siang hingga sore sekolah agama. Di madrasah ini, beliau juga menjadi siswa berprestasi dan didaulat sebagai penceramah cilik dalam setiap sesi wisuda santri.

Tahun 1997, beliau melanjutkan pendidikan Tsanawiyyah hingga Aliyah (setingkat SMP-SMA) di Ponpes Darul Arqam Muhammadiyyah Garut. Ponpes yang memadukan pendidikan Agama dan umum secara proporsional dan telah mencetak banyak alumni yang berkiprah di tingkat nasional dan internasional. Di Ponpes inilah beliau mendapatkan bekal dasar utama dalam berbagai disiplin pengetahuan, baik umum maupun agama. Guru utama beliau, Buya KH. Miskun as-Syatibi ialah orang yang paling berpengaruh dalam menghadirkan kecintaan beliau terhadap al-Qur'an dan pendalaman pengetahuan.

Profil akun Youtube Akhyar TV sangat sederhana yang mengandung beberapa unsur seperti nama, subcriber, jumlah postingan, dan jumlah penayangan. Gambar profil yang digunakan akun Akhyar TV adalah foto logo Akhyar TV yang bertandakan A kecil dengan warna merah seperti ini akhyar TV dengan background warna putih. Identitas lain yang tercantum pada kolom beranda ialah tagline yang bertuliskan "Sajian Terbaik Umat Terbaik". Tagline akun Akhyar TV mengartikan bahwa kita sebagai pendakwah di zaman modernisasi ini harus memberikan sajian terbaik bagi mad'u dengan menyuguhkan tayangan ceramah yang asik tapi tetap pada koridor syariah sesuai Qur'an dan Al-Hadits.

Akun Youtube Akhyar TV merupakan akun Youtube yang dibuat oleh Ust. Adi Hidayat dan team pada tanggal dan tahun 20 Oktober 2016. Team disini terdiri dari bapak Heru Sukari selaku ahli broadcasting beliau juga pendiri

Tabligh: Jurnal Komunikasi dan Penyiaran Islam Vol. 3 No. 3 (2018) 258-274 
Madani TV. Cerita nya saat bertemu dengan Ust. Adi Hidayat dalam kajian nya pada saat itu belum terkenal seperti saat ini. Dalam obrolan selesai kajian, Ust. Adi Hidayat di ajak untuk mengisi di Madani TV awal sebelum adanya Akhyar TV. Lalu dari obrolan itu tergagas untuk mendirikan TV yaitu Akhyar TV dan berkembang hingga membuat akun media sosial di Facebook, Youtube, dan Instagram.

Dalam broadcasting untuk keberlangsungan dakwah Ust. Adi Hidayat, Bapak Heru Sukari dibantu oleh team tenaga ahli broadcast yang bernama mas Sholihan. Untuk yang mengatur media sosial seperti Youtube, Facebook, dan Instagram Akhyar TV dan Google Statistik dikelola oleh kang Yasir dalam mengatur atau sebagai admin nya Akhyar TV. Ust. Adi Hidayat dalam mengatur roda Wasilah al - Da'wah dibantu tenaga tenaga berkompenten dibidang nya tak heran jika Akhyar TV bisa menjelma menjadi Media Dakwah Islam masa kini yang modernisasi tetapi masih dalam koridor Qur'an dan As-Sunnah. (Hasil Wawancara, Jumat 20 April 2018).

Media sosial saat ini menjadi primadona disemua kalangan tanpa memandang usia. Dengan adanya media sosial semua dapat diketahui dalam satu waktu. Tapi media sosial juga terkadang disalah gunakan oleh sebagian besar masyarakat seperti dijadikan media untuk menunjukan kelebihannya, atau sekedar mengunggah atau mengupload video yang tidak bermanfaat. Akhyar TV memiliki cara tersendiri untuk menghindari hal tersebut dengan mengupload konten-konten yang memberikan manfaat dikalangan remaja dan dewasa, karena menurut Ust. Adi Hidayat dalam kajian nya "Sebaik-baiknya Manusia adalah yang paling bermanfaat".

Dengan memanfaatkan media internet yang menjadi salah satu pelopor kemajuan teknologi Ust. Adi Hidayat dan team Akhyar TV mencoba dakwah melalui media sosial Youtube. Ust. Adi Hidayat dan team Akhyar TV mulai merambah dunia dakwah melalui media broadcast dan media sosial di Oktober tahun 2016 hingga sekarang, konten dakwah yang disajikan Akhyar TV berbeda karena menggunakan kamera video bersolusi tinggi sehingga gambarnya jelas sama seperti yang ada di TV komersial hasil gambarnya, karena Akhyar TV disiarkan juga pada satelit palapa sehingga peralatan yang digunakan Akhyar TV team sama dengan TV komersial hasilnya. Ust. Adi Hidayat melalui bapak Heru Sukari saat wawancara ingin akun media sosialnya khususnya akun Youtube Akhyar TV bermanfaat untuk umat karena sama seperti taglinenya "Sajian Terbaik Umat Terbaik" manfaat untuk umat banyak dengan mengajak manusia kepada kebaikkan dan bisa menyadarkan umat Islam bahwa agama Islam adalah agama yang memiliki panduan hidup baik didunia maupun di Akhirat (Hasil Wawancara, Jumat 20 April 2018). 
Video yang di unggah selalu berinovasi megikuti hal-hal yang sedang viral masyarakat saat ini. Dengan menggunakan Retorikanya untuk menghadirkan kajian yang menarik dan diterima disemua kalangan. Hal tersebut memang ciri khas dalam setiap kajian ceramahnya beliau selalu menghadirkan canda tawa saat ceramah membuat menarik mad'u.

Akun Akhyar TV juga mencantumkan kata-kata sebagai mengajak para mad'u nya di media sosial akun Youtube nya seperti ini "Jangan lupa untuk menyebarkan info kebaikan ini, semoga menjadi ladang pahala untuk kita semua, InsyaAllah". Seperti itu lah ajakan kebaikan akun Akhyar TV kepada mad'u nya atau pengikut di media sosial agar dakwah ini tersebar hingga luas. Dalam ajakannya juga akun Akhyar TV mencantumkan kata kata doa untuk pengikut dan pengunjung seperti ini "Semoga Allah senantiasa memudahkan setiap niatan kita untuk mendalami agama, atas perhatiannya kami ucapkan, Jazakallah khairan katsir".

Konten-konten yang diunggah nya memberikan informasi seputar keislaman yang mengajak manusia kepada kebaikkan, baik berupa pesan Akhlak, Ibadah, maupun Aqidah.

Akun Youtube Akhyar TV memilik postingan yang terus bertambah setiap bulannya sesuai jadwal ceramah Ust. Adi Hidayat, selain itu subscriber dan jumlah tayangan terus bertambah setiap waktunya. Untuk menghasilkan cermah yang asik dan menarik, Ust. Adi Hidayat dan team terus gencar berinovasi agar tidak membuat pengunjung dan penonton tayangan ceramah di Akhyar TV antusias saat menonton ceramah Ust. Adi Hidayat di akun Youtube Akhyar TV.

Maka dari itu penelitian ini dilakukan proses menyaksikan secara langsung Dakwah Ustadz Adi Hidayat, maupun melalui media video yang terdapat diyoutube serta hasil wawancara dengan manajemen Akhyar TV dan juga hasil dari beberapa channel Youtube jama'ah yang mengikuti kegiatan Dakwab Ustadz Adi Hidayat secara langsung maupun tidak langsung. Berdasarkan hasil penelitian data yang di dapat sebagai berikut:

\section{Metode Dakwah}

Metode dakwah yang digunakan Ust. Adi Hidayat adalah dengan menggunakan video ceramah melalui Youtube. dengan fitur upload video pada media sosial Youtube semakin mempermudah UAH (Ust. Adi Hidayat) sebagai da'i untuk membagikan dakwahnya dengan menggunakan video. Video yang diunggah nya berdurasi sama seperti lama waktu beliau berceramah yaitu 1 jam stengah. waktu ini sangat cukup untuk pengguna media sosial Youtube memahami isi pelajaran yang baik dari ceramah Ust. Adi Hidayat.

Menyebarluaskan pesan kebaikkan merupakan tanggung jawab seluruh umat Islam. Agar dakwah dapat sampai ke umat maka diperlukan metode yang 
bisa diterima masyarakat. Menurut Sayid Qunub, metode dakwah akan terwujud apabila memenuhi tiga faktor. Pertama, keadaan dan situasi orang-orang yang didakwahi.

Dalam akun Youtube Akhyar TV melihat zaman modernisasi ini sebagai celah untuk menyiarkan dakwah dimana setiap individu tidak akan jauh dari media sosial pada hari ini. Oleh karena itu metode hikmah yang digunakan oleh Ust. Adi Hidayat sesuai keadaan masa kini. Kedua, ukuran materi dakwah yang disampaikan agar mereka merasa tidak keberatan dengan beban materi tersebut, karena Ust. Adi Hidayat selalu jelas saat menjelaskan materinya hingga ke akarakarnya walaupun materinya berat tapi dengan gaya retorika dan daya ingat hafalannya dalam menyampaikan dakwah membuat penonton jadi paham akan materi tersebut.

Metode selanjutnya adalah metode diskusi yang dijalankan dengan format kajian dakwah. Metode ini adalah sering dilakukan oleh semua Ustadz sesudah menerangkan semua bahasan materi dakwah. Dengan metode diskusi ini Ust. Adi Hidayat memberikan kesempatan kepada mad'unya yang hadir di dalam kajiannya dan mad'u nya yang berada di media sosial pun selalu diberikan kesempatan bertanya saat kajian berlangsung melalui teknologi live streaming di Youtube.

Materi dakwah yang disampaikannya bersfiat global sesuai dengan kehidupan sehari-hari agar dapat diterima oleh berbagai kalangan. Disampaikan dengan bahasa yang ringan mengikuti sasaran kajian pada umumnya adalah generasi muda remaja menuju dewasa. Kajian ini bertujuan sebagai pengingat akan pentingnya agama dalam kehidupan serta sebagai ajang sosialisasi dan penyuluhan akan pentingnya berdakwah diera digital saat ini dengan menambahkan kiat-kiat khusus supaya dakwah dapat diterima.

Akun Youtube Akhyar TV memiliki teknik penyampaian dakwah yang berbeda dengan Akun Youtube dakwah lainnya. Pesan dakwah yang disampaikan berbentuk vidoe kajian ceramah yang langsung dari Ust. Adi Hidayat berbeda dengan akun youtube lainnya yang hanya mengcopy video cermah Ust. Adi Hidayat. Bapak Heru Sukari mengatakan saat diwawancarai terkait masalah ini:

"berawal dari latar belakang mendirikan akun Youtube Akbyar TV adalah melihat kesewenangan akun Youtube dakwah yang lain mengambil keuntungan dari kontenkonten dakwabyang kami unggab" (Hasil Wawancara, 20 April 2018).

Metode dakwah dengan menggunakan video membebaskan semua kalangan menonton tanpa ada batasan. Dakwah dengan video ini merupakan cara dakwah yang bersifat fleksibel mengikuti maju nya perkembangan zaman ini. Sifat Ust. Adi Hidayat yang tawadhudan tidak sombong membuat pesan dakwah yang disampaikannya dapat diterima dengan baik oleh penonton nya di 
Youtube.

Dari metode dakwah Ustadz Adi Hidayat dapat di ulas kembali, beliau menggunakan metode dakwah dengan metode penyampaian materi dakwah membuat variasi sedemikian rupa yang sesuai dengan kondisi pada saat itu. Akun Akhyar TV dalam menyampaikan pesan dakwahnya dilakukan dengan video ceramah Ust. Adi Hidayat lalu di unggah ke media sosial Youtube Akhyar TV. Video yang diunggah nya berisikan contoh dan pengajaran bagi umat Islam. Contoh-contoh tersebut ada dalam kehidupan sehari-hari sehingga yang disampaikannya bisa dimengerti dan sudah di alami mad'unya.

Jadi dengan metode video pesan dakwahnya dapat sampai mudah, dan orang-orang yang menontonnya juga memahami inti dari dakwahnya tersebut. Metode ini mempunyai posisi yang paling penting sebagai penentu kesuksesaan berdakwah di era modern ini.

Metode kedua yang diterapkan oleh akun Akhyar TV dalam berdakwah adalah dengan metode tulisan, dalam setiap kajiannya Ust. Adi Hidayat selalu menggunakan papan tulis untuk menjelaskan kepada mad'unya. Seperti yang dibahas di atas mengapa Ust. Adi Hidayat materi kajian nya berat tetapi tetap diterima oleh masyarakat banyak, karena beliau rinci menjelaskan ayat per ayat hingga halamannya dan begitu juga dengan menjelaskan hadits hingga halamanya, menjelaskan hadits perawinya jelas di saat Ust. Adi Hidayat menjelaskan materi. Itu karena Ust. Adi Hidayat mempunyai daya ingat hafalan Qur'an dan hadits yang baik sehingga membuat mad'unya mengerti.Tulisan penjelasan tersebut memiliki isi pelajaran dan nasihat yang baik agar kita saat menjelaskan suatu materi harus dengan sumber yang jelas dan jelas materi yang akan disampaikan. Perkataan baik yang dapat menyentuh perasaan sehingga dapat membangkitkan semangat untuk mengamalkan syari'at Islam.

Ust. Adi Hidayat selaku pemilik akun Youtube Akhyar TV mampu menyajikan pesan dakwahnya sesuai dengan kemampuan yang beragam mad'unya dan kemampuan Ust. Adi Hidayat. Nasihat-nasihat yang disampaikannya menggunakan video dan dilengkapi dengan penjelasan Al-Qur'an dan Hadits yang rinci sebagai metode dakwahnya sebagai pengingat yang senantiasa membimbing untuk menghindari hal-hal yang mengandung kemaksiaatan.

Nasihat-nasihat yang dijelaskan Ust. Adi Hidayat merupakan pengalaman beliau sebagai lulusan timur tengah sehingga memiliki ilmu pengetahuan agama yang sangat baik.

Metode selanjutnya adalah metode diskusi yang dijalankan dengan format kajian dakwah. Metode ini adalah sering dilakukan oleh semua Ustadz sesudah menerangkan semua bahasan materi dakwah. Dengan metode diskusi ini Ust. Adi Hidayat memberikan kesempatan kepada mad'unya yang hadir di dalam kajiannya dan mad'u nya yang berada di media sosial pun selalu diberikan kesempatan bertanya saat kajian berlangsung melalui teknologi live streaming di 
Youtube.

Materi dakwah yang disampaikannya bersfiat global sesuai dengan kehidupan sehari-hari agar dapat diterima oleh berbagai kalangan. Disampaikan dengan bahasa yang ringan mengikuti sasaran kajian pada umumnya adalah generasi muda remaja menuju dewasa. Kajian ini bertujuan sebagai pengingat akan pentingnya agama dalam kehidupan serta sebagai ajang sosialisasi dan penyuluhan akan pentingnya berdakwah diera digital saat ini dengan menambahkan kiat-kiat khusus supaya dakwah dapat diterima. Metode diskusi ini hanya dilakukan melalui kajian dan live streaming diskusi tanya jawab juga dilakukan melalui live streaming Youtube.

Dengan menggunakan ketiga metode tersebut hingga kini UAH masihn terus bergerak untuk mensyiarkan ajaran Islam. Ketiga metode tersebut dapat disampaikan ditunjang dengan kemampuan beliau dalam ilmu agama yang sangat baik. Sebelum pesan dakwah disampaikan dengan baik kepada audiens, terdapat proses dan tahapan-tahapan agar pesan dakwah tersebut disalurkan dengan baik.

Akun Youtube Akhyar TV memiliki teknik dengan penyampaian dakwah yang harus berbeda dengan Akun Youtube dakwah lainnya. Pesan dakwah yang disampaikan berbentuk vidoe kajian ceramah yang langsung dari Ust. Adi Hidayat.

\section{Peran Admin}

Dalam pelaksanaannya, tugas dakwah ini mirip dengan tugas kerasulan Nabi Muhammad SAW yang berusaha menyebarkan ajaran Islam kepada seluruh umat manusia secara universal, dan membawa misi dakwahuntuk memperingatkan dan memanggil manusia ke jalan yang benar.

Dakwah dilakukan sebagai bentuk ibadah yang dilakukan manusia untuk mengingatkan orang lain agar dapat berubah menjadi lebih baik sesuai dengan syariat Islam yang kaffah. Seiring berkembang nya zaman, dakwah tidak hanya terbatas pada ceramah-ceramah di masjid tetapi berkembang melalui I'lamsalah satunya yaitu melalui media sosial.

Media sosial adalah aplikasi yang berada dijaringan internet dan dikendalikan oleh admin. Admin bertugas untuk merancang konten konten dakwah, menulis konten dakwah, memposting, dan memberikan respon komentar yang masuk ke media sosial tersebut. Tanggung jawab yang besar membuat admin media sosial harus berfikri kreatif dan inovatif agar konten yang dirancang mendapatkan respon yang positif dari pengguna media sosial. Admin memiliki fungsi yang penting, karena berjalannya media sosial tergantung kreatifitas dan keaktifan admin media sosial tersebut.

Pada akun Akhyar TV admin bertugas untuk merancang konten konten dakwah, menulis konten dakwah, memposting, dan memberikan respon 
komentar yang masuk ke media sosial tersebut. Tanggung jawab yang besar membuat admin media sosial harus berfikri kreatif dan inovatif agar konten yang dirancang mendapatkan respon yang positif dari pengguna media sosial. Admin memiliki fungsi yang penting, karena berjalannya media sosial tergantung kreatifitas dan keaktifan admin media sosial tersebut.

Pada akun Akhyar TV yang bertugas sebagai admin adalah Yasir, Kang Yasir ini orang yang dipercayai sebagai admin Akhyar TV nya Ust. Adi Hidayat dan bapak Heru Sukari selaku pendiri dan Ahli Broadcast Akhyar TV. Dengan kemampuan Broadcasting nya bapak Heru Sukari dan Kang Yasir ini, membantu Ust. Adi Hidayat menjalankan dakwah dengan memanfaatkan media sosial Youtube sebagai media dakwah modern ini.

Sebagai admin kang Yasir menjalankan akun Youtube Akhyar TV dengan konsisten terbukti dengan konten yang di unggah Akhyar TV selalu konsisten berinovasi dalam penyajian dakwah nya. Pesan dakwah yang di kemas melalui video kajian Ust. Adi Hidayat merupakan ceramah ceramah Ust. Adi Hidayat yang setiap kajian nya di unggah ke media sosial Youtube Akhyar TV.

Tujuan dakwah yang dilakukan Akhyar TV dengan menggunakan media sosial adalah memfasilitasi umat agar yang tidak bisa ikut kajian Ust. Adi Hidayat bisa melihat disiaran ulang nya di akun Youtuba Akhyar TV. Dan mengajak pengguna Youtube untuk lebih memanfaatkan media Youtube sebagai wadah untuk menambah pengetahuan keislaman.

Mengingatkan mereka akan hak dan kewajiban mereka sebagai umat muslim untuk senatiasa beribadah kepada Allah SWT. Sebagai pengingat pentingnya syiar Islam dizaman modern saat ini. Serta sebagai pembimbing perubahan akhlak manusia yang sudah dijajah oleh teknologi. Tidak hanya itu, postingan yang diunggah oleh Akhyar TV digunakan sebagai motivasi untuk orang lain agar ikut berperan dalam dakwah Islam (Hasil Observasi, 3 Agustus 2018).

Teknologi semakin canggih menuntut dakwah untuk selalu berinovasi dalam mengemas konten nya, tidak hanya dengan melalui ceramah, atau kajian majelis ta'lim. Dakwah haruslah mengikuti perkembangan zaman agar dakwah tidak ditinggalkan. Pesan dakwah yang disampaikan harus tetap ada agar umat muslim memiliki pengingat dalam menjalankan kehidupan. Kemunculan mediamedia sosial memberikan kemudahan manusia untuk berdakwah secara lebih luas dan lebih cepat.

Dakwah melalui media sosial terbukti bisa membuat seseorang berubah, meskipun tidak dengan cepat tapi sedikit demi sedikit orang tersebut memperbaiki dirinya.

Pesan Dakwah

Dakwah pada hakikatnya adalah menyampaikan pesan-pesan kebaikan kepada umat manusia supaya manusia tersebut menjadi lebih baik. Pesan 
dakwah tersebut disampaikan oleh pelaku dakwah kepada sasaran dakwah atau mad'u yang dalam hal ini mad'unya adalah pengikut akun Youtube Akhyar TV. Tema yang dibahas UAH (Ust. Adi Hidayat) tidak jauh seputar kehidupan beragama seperti hijrah, dan hal-hal yang sedang menjadi viral dikalangan masyarakat muslim Indonesia.

Pesan dakwah ini adalah alat atau sarana yang digunakan untuk proses penyampaikan dakwah itu sendiri. Karena dakwah ini adalah proses tabligh secara lisan yang biasa disampaikan melalui media digital sosial atau sarana tabligh lainnya seperti peran media majelis taklim media dakwah yang umum diadakan sebagai proses penyebarluasan ajaran Islam (Sukayat, 2015: 27).

Selain itu, menurut Muhammad Said Mubarak dalam Dasar-dasar Ilmu Dakwah, al-wushlah yakni alat yang menjadi perantara untuk menyampaiakan sesuatu kepada yang dituju. Selajutnya, menurut beliau terdapat dua bentuk washilah dalam dakwah, yakni maknawiyah yakni perantara yang dilakukan oleh seorang penceramah dalam berdakwah. Kemudian madiyah yakni berupa masjid dimimbar atau media dakwahnya (Enjang AS, Aliyudin, 2009: 94).

Tidak hanya menyajikan pesan dakwah yang serius, konsep dari video yang telah diunggah adalah kajian yang diisi dengan tanya jawab mad'unya baik yang mengikuti kajiannya ditempat maupun pemirsa yang ada luar kajian melalui live streaming Youtube.

Sehingga akun Youtube Akhyar TV memiliki daya tarik tersendiri untuk memikat hati para pengikutnya. Akun Akhyar TV selalu memberikan inovasi dalam setiap unggahannya sehingga terlihat menarik.Materi pesan dakwah yang disampaikan berupa materi tentang akhlak, aqidah, dan fiqh yang bersumber dari Al-Qur'an dan As-Sunnah yang sesuai dengan kehidupan sehari-hari.

Pemilihan materi dilakukan secara cermat yang sesuai dengan situasi dan kondisi saat ini. Materi pesan dakwah yang diunggah sebagian besar ditunjukan kepada generasi muda remaja menuju dewasa pria dan wanita. Dari 10 video unggahan yang telah diunggah oleh akun Youtube Akhyar TV dapat diketahui bahwa kategori pesan dakwah yang memiliki muatan Aqidah sebanyak 3 unggahan, Fiqh sebanyak 3 unggahan, dan Akhlak sebanyak 4 unggahan.

Dari data diatas disimpulkan bahwa akun Youtube Akhyar TV lebih banyak menyampaikan pesan Akhlak yaitu sebanyak 4 unggahan sedangkan jumlah Aqidah dan Fiqh jumlahnya sama 3 unggahan. Hal tersebut dilatar belakangi dengan krisis moral masyarakat Indonesia khususnya generasi muda. Untuk memperbaiki itu semua Ust. Adi Hidayat coba dengan lebih mengutamakan pesan dakwah berisi muatan Akhlak.

Dari uraian diatas pada prinsipnya media kbithabah adalah berbagai alat (instrument), sarana yang dapat digunakan untuk pengembangan dakwah Islam yang mengacu pada kultur masyarakat dari yang klasik, tradisional, sampai 


\section{Maulana, Ch. Saefullah, T. Sukayat}

modern diantaranya meliputi mimbar, panggung, media massa cetak dan elektronik, lembaga, organisasi (Enjang AS, Aliyudin, 2009: 95).

Maka dari itu media dakwah yang digunakan Ustadz Adi Hidayat dalam berdakwah yakni media dakwahnya secara langsung yaitu melalui media digital sosial ketika khutbah atau ketika ceramah di pengajian atau majelis taklim. Berdasarkan tabel kategorisasi pesan dakwah diatas terdapat tiga pesan dakwah yang telah diunggah oleh akun Akhyar TV, yaitu pesan Aqidah, Akhlak, dan Fiqh yang bersumber dari Al-Qur'an, Hadits Rasulullah SAW, dan kisah hikmah sahabat yang menginspirasi.

Berikut akan dipaparkan sebagai pesan dakwah yang disampaikan oleh akun Akhyar TV melalui media sosial Youtube:

Pesan Dakwah Aqidah

Pesan Aqidah merupakan pesan dakwah yang paling utama. Aqidah Islam adalah kesaksian bahwa tidak ada tuhan selain Allah dan Muhammad itu utusan Allah. Permasalahan Aqidah dalam Islam mengcakup masalah keyakinan yang erat hubungan nya dengan rukun iman. Karena aspek atau keimanan merupakan komponen utama yang harus ada pada diri manusia untuk membentuk moral dan akhlakul karimah.

Iman adalah mutiara didalam hati manusia yang meyakini Allah SWT Maha esa Maha kuasa, Iman kepada Malaikat, Iman kepada Kitab, Iman kepada Rasulullah, Iman kepada Hari akhir, dan Iman Kepada Qada dan Qadhar.

Kemudian jika dikaitkan dengan teori Harold Lasswell yakni In Whit Channel, yakni dalam proses komunikasi atau kbithabah tentunya tidak lepas dari perantara suatu media itu sendiri (Mulyana, 2008: 148).

Maka dari itu berdasarkan penelitian yang peneliti amati terkait dengan media dakwah yang Ustadz Adi Hidayat gunakan dalam ceramahnya Ustadz Adi Hidayat tidak lepas dari pesan-pesan dakwah yang menyuguhkan pesan aqidah, akhlak maupun fiqh didalam dakwahnya.

Pesan dakwah berupa ibadah merupakan jantung dan pokok kajian yang tidak dapat dipisahkan dari kehidupan umat muslim. Ibadah dengan menyembah Allah disusun dalam suatu ilmu yaitu syari'ah dan ilmu Fiqh yang membahas tentang syahadat, shalat, zakat, puasa dan berhaji.

Maka dari dakwah Ustadz Adi Hidayat tentunya tidak hanya menggunakan media khithabah pada umumnya yakni lewat peran media mimbar atau di majelis taklim. Namun beliau pun sudah merambah menggunakan media apa saja sesuai perkembangan media pada zaman modern saat ini seperti televisi, radio, serta media sosial berbasis video seperti youtube.

Maka dari itu dakwah Ustadz Adi Hidayat lebih luas dan mudah di terima oleh jama'ah dari kalangan mana pun tidak terbatas oleh ruang dan waktu. Sehingga tetap memungkinkan dalam keadaan kondisi apapun, dalam keadaan sibuk atau pun luang jama'ahnya masih dapat menikmati dan mendengarkan 
Dakwah Ustadz Adi Hidayat.

\section{PENUTUP}

Admin pada akun Akhyar TV bernama kang Yasir beliau adalah seorang ahli IT yang mengatur berjalannya akun media sosial Akhyar TV termasuk Youtube Akhyar TV. Dan da'i pada akun Akhyar TV adalah Ust. Adi Hidayat seorang ulama yang dengan kemampuan hafalan Al-Qur'an dan Haditsnya, meskipun Ust. Adi Hidayat seorang Ustadz yang menurut sebagian orang tidak mengerti teknologi beliau melakukan dakwah itu lewat media sosial. Tidak dipungkiri lagi dakwahnya yang lugas dan tegas dapat masuk ke dalam hati para masyarakat muslim indonesia dengan Dakwah di Media sosialnya yang semakin berkembang mengikuti zaman untuk memperbaiki Akhlak masyarakat Indonesia.

Video ceramah Ust. Adi Hidayat yang diunggah oleh Akun nya Akhyar TV memberikan efek yang baik kepada pengikutnya di sosial media Youtube. Banyak diantara mereka yang kagum akan ceramah beliau yang tegas jelas tapi menarik perhatian untuk melihat ceramahnya dengan berkala para pengikutnya mau merubah diri.

Metode Dakwah yang dilakukan oleh akun Akhyar TV dengan menggunakan metode video ceramah yang diunggah ke media sosial yang bersifat bijaksana dan jelas dalam menerangkan materi dakwahnya. Metode tulisan yang diterapkan adalah menulis dipapan tulis menggunakan papan tulis dikajian nya Ust. Adi Hidayat menjelaskan materinya melalu media papan tulis dan Akhyar TV sebagai media untuk ditayangkan tulisan materinya ke penonton Youtube Akhyar TV. Metode diskusi dalam bentuk kajian untuk mempengaruhi orang lain untuk ikut terjun ke dunia dakwah. Agar tercapai metodenya tersebut dilakukan dengan menggunakan video yang sedang berlangsung maupun yang tayangan ulang diunggah ke Youtube Akhyar TV.

Pesan Dakwah yang terdapat pada akun Akhyar TV bertujuan untuk merubah perilaku masyarakat khususnya Indonesia agar bisa bermanfaat untuk orang lain karena pesan dakwah yang disampaikan terkait semua sisi kehidupan masyarakat modern baik dari segi Aqidah, Fiqh (Ibadah), dan Akhlak. Akun Akhyar TV memberikan sajian materi pesan dakwah yang bersumber dari AlQur'an dan Hadits yang berkaitan dengan kehidupan sehari-hari, seperti slogannya "sajian terbaik umat terbaik".

Kepada Ustadz Adi Hidayat, Sebagai akun yang bergerak dibidang dakwah, Akhyar TV perlu terobosan baru dalam mengembangkan dakwahnya dengan melakukan inovasi baru terus menerus agar dakwahnya tetap menjadi pilihan "umat terbaik" sesuai slogannya.

Program kajian yang dilakukan Ust. Adi Hidayat sebaiknya dilakukan dimasjid-masjid kecil agar tidak hanya didaerah kota saja tapi sampai ke 


\section{Maulana, Ch. Saefullah, T. Sukayat}

pedalaman penjuru desa agar dakwah Ust. Adi Hidayat dan konten dakwah Akhyar TV beragam mad'unya dan pengikutnya diYoutube.

Dalam penyajian ceramah dakwah Ust. Adi Hidayat saat live masih ada saja yang terkoneksikan lama sehingga buka video nya suara tidak ada dan layar masih hitam kosong belum ada gambarnya. Agar dakwah semakin baik diperbaiki lagi sistem koneksinya agar penonton Youtube Akhyar TV tidak kecewa dengan penyiaran ceramahnya Ust. Adi Hidayat.

Kepada aktivis dakwah khithabah lakukan dakwah dimanapun dan kapanpun, tetaplah berinovasi dalam kemajuan dakwah khususnya dakwah billisan, adakan generasi cinta dakwah untuk membangun peradaban dakwah untuk menghadapi tantangan zaman yang semakin maju dan berkembang. Tetaplah berdakwah untuk menciptakan perubahan yang lebih baik di masa depan.

\section{DAFTAR PUSTAKA}

Kusnawan, A. (2016). Teknik Penulisan Dakwah. Bandung: Simbiosa Rekatama Media

Kusnawan, A. (2004). Komunikasi dan Penyiaran Islam, Bandung: Benang merah.

Kusnawan, A. (2004). Ilmu Dakwah (kajian Berbagai Aspek), Bandung: Pustaka Bani Quraisy.

A.S, Enjang \& Aliyudin. (2009). Dasar-dasar Ilmu Dakwah, Bandung: Widya Padjadjaran

Kusnawan, A, dkk. (2004). Ilmu Dakwah (Kajian berbagai Aspek), Jakarta: Pustaka Bani Quraisy

Mulyana, D. (2008). ILMU KOMUNIKASI Suatu Pengantar, Bandung: PT REMAJA ROSDAKARYA.

Fakhruroji, M. (2017). Dakwah di Era Media Baru. Bandung: Simbiosa Rekatama Media

Nasrullah, R. (2017). Media Sosial Perspektif Komunikasi, budaya, dan Sosioteknolog. Bandung: Simbiosa Rekatama Media.

Saputra, W.(2004). Pengantar Ilmu Dakwah, Jakarta: Rajawali Pers

Munir, M. (2003). Metode Dakwah, Jakarta: Kencana

Sukayat, T. (2009). Quantum Dakwah, Jakarta: Rineka Cipta

Sukayat, T. (2015). Ilmu Dakwah Perspektif Filsafat Mabadi A'syarah, Bandung: Simbiosa Rekata Media

Supena, I. (2013). FILSAFAT ILMU DAKWA Perspektif Filsafat Ilmu Sosial, Yogyakarta: Ombak (Anggota IKAPI).

Zaini, A. (2013). Dakwah melalui mimbar dan Khithabah dalam Jurnal Komunikasi dan Penyiaran Islam, 1(2). 